\title{
Domateste bakteriyel benek hastalığının mücadelesinde vermikompost uygulamasının etkisi
}

The effect of vermicompost treatment on the control of bacterial speck disease on tomato

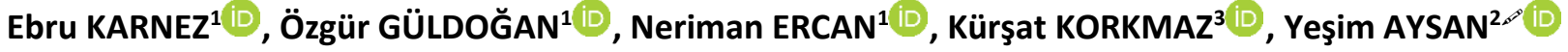 \\ ${ }^{1}$ Çukurova Üniversitesi, Karaisalı Meslek Yüksekokulu, Bitkisel ve Hayvansal Üretim Bölümü, Karaisalı, ADANA. \\ ${ }^{2}$ Çukurova Üniversitesi, Ziraat Fakültesi, Bitki Koruma Bölümü, Sarıçam, ADANA. \\ ${ }^{3}$ Ordu Üniversitesi, Ziraat Fakültesi, Toprak Bilimi ve Bitki Besleme Bölümü, ORDU
}

\section{MAKALE BILGISI / ARTICLE INFO}

\section{Makale tarihçesi / Article history:}

DOI: $10.37908 /$ mkutbd.986521

Geliş tarihi /Received:24.08.2021

Kabul tarihi/Accepted:02.10.2021

\section{Keywords:}

Plant nutrition-disease, macro and micro elements, bacteria, Pseudomonas, vermicompost.

\footnotetext{
Corresponding author: Yeşim AYSAN

$\triangle$ : aysanys@gmail.com
}

\section{ÖZET / A B STR A C T}

Atıf / Citation: Karnez E, Güldoğan Ö, Ercan N, Korkmaz K, Aysan Y (2021) Domateste bakteriyel benek hastalığının mücadelesinde vermikompost uygulamasının etkisi. MKU. Tar. Bil. Derg. 26(3) : 726-735. DOI: 10.37908/mkutbd.986521

\begin{abstract}
Aims: Tomato bacterial speck disease, caused by Pseudomonas syringae pv. tomato, leads significant yield losses in plants grown in nursery, field and greenhouse conditions. The aim of the research on the relationship between plant nutrition and disease, is to determine the suppression level of the disease by using vermicompost fertilization. In addition, the changes in the levels of macro ( $\mathrm{N}, \mathrm{P}, \mathrm{K}, \mathrm{Ca}, \mathrm{Mg}$ ) and micro ( $\mathrm{Fe}, \mathrm{Cu}, \mathrm{Zn}, \mathrm{Mn}$ ) element concentrations on diseased plants with and without vermicompost were investigated in pot experiments.

Methods and Results: In the experiments, solid and liquid forms of the vermicompost were applied to the soil and leaves, respectively. Inoculated plants with the pathogen was used as positive control and the effect of vermicompost on the disease was evaluated by two pot experiments. Vermicompost suppressed the disease on the first experiment in greenhouse by $34-39 \%$, on the second experiment in climate room by 12 $42 \%$. The mean disease incidences were significantly reduced $(P \leq 0.05)$ by vermicompost treatment with foliar and soil applications in the experiments. When vermicompost was treated as a combination of soil and foliar applications to the diseased plants, the increases in uptake of total $\mathrm{N}, \mathrm{Mg}, \mathrm{Cu}, \mathrm{P}$ and $\mathrm{Mn}$ were $80.95,74.60,46.40,38.18$ and $5.24 \%$, respectively. The increases in uptake of $\mathrm{Ca}$ and $\mathrm{Fe}$ were $103.77 \%$ and $45.35 \%$ by soil applications while the increased levels were $31.21 \%$ and $8.42 \%$ by foliar applications.

Conclusions: The contents of macro and micro nutrients were increased by vermicompost on tomato and the disease was highly suppressed by vermicomposts. As a result of the research, vermicompost should be applied by a combination of soil and foliar treatments in order to succesfully absorb the macro and micro nutrients.

Significance and Impact of the Study: To the our knowledge, the study is the first research on control of bacterial speck disease of tomato by vermicompost applications. Moreover, it is also the first study on the uptake level of macro and micro nutrients of diseased plants.
\end{abstract}




\section{GiRiş}

Bitki bakteriyel hastalık etmeni Pseudomonas syringae'nin farklı patovarları (alt türleri) fitotoksinler üretmek suretiyle konukçu bitkilerinde yaprak, çiçek, dal ve sürgün yanıklıklarına neden olur. Bu patojen bakteri türünün domatesi hastalandıran alt türlerinden biri Pseudomonas syringae pv. tomato olup, ürettiği koronatin isimli fitotoksin nedeniyle domateste bakteriyel benek olarak bilinen hastalığı neden olur. Hastalığın görüldüğü domates bitkisinin çiçeklerinde yanıklık, gövdelerde uzun siyah lezyonlar ve yapraklarda sarı haleli kahverengi lekeler meydana gelir. Hastalık ticari domates fidesi üretilen alanlarda, tarlada ve serada önemli verim kayıplarına sebep olur (Aysan ve Saygılı, 2019).

Hastalık etmeni bakteri domates tohumunda ve topraktaki bitki artıklarında yaşamını devam ettirerek bir sonraki üretimi de tehdit edebilir. Bu nedenle bitki bakteriyel hastalıkların entegre yönetiminde başta sağııkı tohum kullanımı olmak üzere, üretim esnasında hijyen kurallarına uyma, bitkiyi dengeli gübreleyerek veya bitki aktivatörleri tarafından hastalığa dayanıklı kılmak, antagonistik mikroorganizmalar, metal nanopartikül, bitki uçucu yağ ve ekstraktlarından faydalanma, bakırlı preparatlarla yeşil aksam püskürtmeleri ve toprak solarizasyonu önemli mücadele stratejileri etkin yöntemler olarak kullanılabileceği bildirilmiştir (Miller ve Jones, 2014; Aysan ve Saygılı, 2019; Bozkurt ve Soylu, 2019; Bozkurt ve ark., 2020; Aktepe, 2021; Bitgen ve Mirik, 2021; Şahin ve ark., 2021). Ancak bu patojenik bakterinin bakırlı prepartlara duyarlılığının azalması (Benlioğlu ve Benlioğlu, 1998) sonucu son yıllarda kimyasal mücadeleden yeterli başarı elde edilememektedir. Bu hastalığa dayanıklı domates çeşitlerinin olmaması da göz önüne alındığında bitkiyi hastalıklara dirençli kılmak önemli bir mücadele adımı olarak değerlendirilebilir.

Domatesi pek çok hastalığa dayanıklı kılmak için topraktaki ve yeşil aksamdaki faydalı mikroorganizmaların popülasyonlarını artırmak ve bitkiyi doğru gübrelemek oldukça önemlidir. Kimyasal gübreler ve pestisitler bu faydalı mikroorganizmaların popülasyonunu azaltabilir. Bunların yerine, öncelikli olarak topraktaki mikrobiyal aktiviteyi artıran bunun yanında bitkiye yarayışı besin elementlerinin alımını sağlayarak tohum çimlenmesini ve fide büyümesini artıran uygulamalardan, çevreyle dost ve yüksek ekonomik değere sahip bir materyal olan vermikompost (solucan gübresi) uygulaması öneriler arasındadır. Solucan gübresi olarak da bilinen vermikompost, sebze veya gıda atıklarının solucanların sindirim sistemlerinden geçirilmesi sonucu elde edilen bir gübredir (Chaoui ve ark., 2002). Solucanların eski çağlardan bu yana toprak altında yaşamlarını sürdürürken, milyonlarca yıl maruz kaldığı patojenlere karşı savunma mekanizması geliştirdiği ve bu mekanizmada da antibiyotik bariyeri ve doğal bağışıklığın ana rolü oynadığı belirlenmiştir (Zhenjun, 2011). Bu nedenle solucanlardan elde edilen vermikompost sadece bitkinin verimini, kalitesini iyileştirici özelliğe sahip olmakla kalmayıp aynı zamanda hastalıklara karşı direncini de artırır. Örtü altı ve saksı yetiştiriciliğinde ülkemizde kullanımı hızla artan vermikompost (solucan gübresi) ürünleri son 40 yılda, İngiltere, $A B D$, Avustralya gibi gelişmiş ülkeler ile Hindistan, Brezilya, Filipinler, Küba gibi gelişmekte olan ülkelerde de yaygın olarak kullanılmaktadır.

Bitki besleme ve hastalık ilişkisini içeren bu araştırmada, topraktan, yapraktan ve hem toprak hem de yapraktan vermikompost uygulamalarının domateste bakteriyel benek hastalığını ne oranda baskıladığı iklim odası ve cam serada yapılan saksı denemeleriyle ortaya konmuştur. Ayrıca vermikompost uygulaması yapılmış bakteriyel benek hastalı̆̆ ile enfekteli domates bitkilerinin makro ( $\mathrm{N}, \mathrm{P}, \mathrm{K}, \mathrm{Ca}, \mathrm{Mg}$ ) ve mikro ( $\mathrm{Fe}, \mathrm{Cu}, \mathrm{Zn}$, $\mathrm{Mn})$ besin elementi konsantrasyonlarındaki değişim incelenmiştir.

\section{MATERYAL ve YÖNTEM}

\section{Materyal}

Patojen bakteri izolatı: Çukurova Üniversitesi Ziraat Fakültesi Bitki Koruma Bölümü bakteriyoloji laboratuvarı kültür koleksiyonlarında bulunan YA-581 kodlu Pseudomonas syringae pv. tomato izolatı çalışmada kullanılmıştır. Bu izolat Adana ili Karataş ilçesinden hasta domates bitkilerinden izole edilmiş ve tanısı morfolojik, fizyolojik, biyokimyasal ve patojenite testleriyle yapılmıştır.

Besi yerleri: Patojen bakterinin çoğaltılmasında Pseudomonas Agar F Base (10 g Protose Pepton, $10 \mathrm{~g}$ Tryptone, $10 \mathrm{ml}$ Gliserin, $1.5 \mathrm{~g} \mathrm{~K}_{2} \mathrm{HPO}_{4}, 1.5 \mathrm{~g} \mathrm{MgSO}_{4}$ $7 \mathrm{H}_{2} \mathrm{O}, 15 \mathrm{~g}$ Agar $1000 \mathrm{ml}$ distile su) ve Tryptone Soy Agar (TSA) besi yerleri kullanılmıştır (Saygılı ve ark., 2006; Soylu ve ark., 2020a).

Vermikompost: Denemelerde kullanılan vermikompost ticari amaçlı üretim yapan Agrosol Solucan Gübresi (http://agrosolgubre.com/) firmasından temin edilen "Agrosol Katı Solucan Gübresi" adlı ticari bir üründür. İçerik olarak katı vermikompost; pH: 7.50, organik madde \%30.33, toplam asit (hümik+fulvik) \%15.22, toplam $\mathrm{P}_{2} \mathrm{O}_{5} \% 1.06$ ve suda çözünür $\mathrm{K}_{2} \mathrm{O} \% 1.55$ içermektedir ve gübre granül formdadır. 
Denemelerdeki tüm vermikompost uygulamalarında üretici firmanın önerdiği doz olan; topraktan katı vermikompost uygulamalarında $\% 20$, yapraktan SIVI olarak el pülverizatörü kullanılarak yapılan uygulamalarda \%5 oranı kullanılmıştır. Uygulama dozuna sebzelerde yaygın olarak kullanılan ve üretici firmanın önerisi olan doz göz önünde bulundurularak karar verilmiştir. Katı vermikompost $25 \mathrm{~kg} / \mathrm{lk}$ kapalı paketlerde, sIVı vermikompost ise solüsyon halinde ambalajlı şekilde firma tarafından temin edilmiştir.

Domates fideleri: Saksı denemelerinde bakteriyel hastalıklara duyarlı domates çeşitleri olan Panzer ve Anıt 171 kullanılmıştır. Denemelerde kullanılan domates fideleri, ticari bir fidelikte yetiştirilmiştir.

Iklim odası: Çukurova Üniversitesi, Ziraat Fakültesi, Bitki Koruma Bölümünde bulunan, 16:8 saat aydınlatmalı, $\% 75$ nem, $25 \pm 2{ }^{\circ} \mathrm{C}$ sıcaklık, klima ile ısıtılan/soğutulan iklim odası koşullarında saksı denemesi kurulmuştur.

Cam sera: Çukurova Üniversitesi, Ziraat Fakültesi, Bitki Koruma Bölümü Deneme ve Araştırma parsellerinde bulunan yüksek tip ısıtmasız cam serada saksı denemesi kurulmuştur.

\section{Yöntem \\ Vermikompost uygulamasının bakteriyel benek hastalığına etkisi}

Çalışmanın bu aşamasında, vermikompost uygulamasının domateste bir yaprak hastalığı olan Pseudomonas syringae pv. tomato'nun neden olduğu bakteriyel benek hastalığına ve hastalıklı bitkilerin bitki besin elementi konsantrasyonu üzerine etkisini belirlemek amacıyla iki adet saksı denemesi kurulmuştur. Denemede kullanılan katı vermikompost topraktan, sIVI vermikompost ise yapraktan yapılan uygulamalar için kullanılmıştır. Katı ve sıvı vermikompost (1) topraktan , (2) yapraktan ve (3) hem toprak hem de yapraktan olmak üzere üç farklı şekilde uygulandığında bakteriyel benek hastalığını ne oranda baskıladığı araştırılmıştır. Denemede pozitif kontrol olarak vermikompost uygulaması yapılmamış sadece patojen bakteri Pseudomonas syringae pv. tomato ile bulaştırımış bitkiler ve negatif kontrol olarak sadece su püskürtülmüş bitkiler yer almıştır.

Her uygulamada beş tekrar ve her tekrarda 3 bitki olacak şekilde deneme kurulmuş ve çalışmada toplam 75 adet domates bitkisi kullanılmıştır. Torf ve toprak içeren yetiştirme ortamı iklim odası denemesinde $0,5 \mathrm{~kg}$, cam sera denemesinde 2,5 kg'lık saksılar kullanılarak yapılmıştır.

Bakteriyel benek hastalığı etmeni Pseudomonas syringae pv. tomato'nun optimum gelişme sıcaklığının $20-22^{\circ} \mathrm{C}$ olması nedeniyle birinci deneme Mart ayında cam serada diğeri ise Kasım ayında iklim odasında saksı çalışması şeklinde kurulmuştur. Cam seradaki birinci denemede Panzer çeşidi, iklim odasındaki ikinci denemede Anıt 171 çeşidi domates fideleri kullanılmıştır. Bitkiler saksılara şaşırtılııtan 10 gün sonra negatif kontrol hariç tüm uygulamalardaki domates bitkilerine patojen bakteri olan Pseudomonas syringae pv. tomato suni olarak bulaştırılmıştır. TSA besi yerine çizimi yapılan patojen bakteri $25^{\circ} \mathrm{C}^{\prime}$ deki inkübatörde 48 saat geliştirilmiştir. İnkübasyon süresi sonunda gelişen saf bakteri kültüründen steril su ile bakteri süspansiyonu hazırlanmıştır. Dansiyometre kullanılarak ml'deki bakteri popülasyonu $10^{7}$ hücreye ayarlanmıştır. Hazırlanan patojen bakteri süspansiyonu bir el pülverizatörüyle yaprakların altına eşit oranda püskürtülmüştür.

Deneme süresince bitkilere bahsedilen uygulamaların dışında başka bir kimyasal ve gübre uygulaması yapılmamış, bitkiler düzenli olarak sulanmış ve hastalık gelişimi açısından her gün kontrol edilmiştir.

Pozitif kontrol bitkilerinin yapraklarında nekroz ve kloroz içeren tipik hastalık lekeleri gözlendikten sonra değerlendirme 0-5 skalasıyla (0: hastalık belirtisi yok; 1 : yaprak alanının \%1-15 lekeli; 2: yaprak alanının \%16-30 lekeli; 3: yaprak alanının \%31-45 lekeli; 4: yaprak alanının \%46-60 lekeli; 5: yaprak alanının \%61'den fazlası lekeli) yapılmıştır (Karabüyük ve Aysan, 2019). Her bitkiden üçer yaprak alınarak, her uygulamadan toplam 45 yaprak 0-5 skalasına göre değerlendirilerek skala değerleri not edilmiştir. Uygulamaların etkisi, pozitif kontrol ile karşılaştırılarak Abbott formülüyle (\% etki: ((kontroluygulama/kontrol) $\times 100$ ) ortaya konmuştur (Karman, 1971). İstatistiki farklar hesaplanırken, ANOVA istatistik programında LSD çoklu karşılaştırma testinde $P \leq 0.05$ önem düzeyinde aynı istatistiki grupta yer alan uygulamalar aynı harfle işaretlenerek sonuçlar yorumlanmıştır.

\section{Vermikompost uygulamasının bakteriyel benek hastalığıyla enfekteli domates bitkilerinin besin elementi içeriği üzerine etkisi}

Vermikompost gübrelemesi yapılmış ve bakteriyel benek hastalığı etmeni Pseudomonas syringae pv. tomato ile enfekteli domates bitkilerinin topraktan kaldırdığı makro $(\mathrm{N}, \mathrm{P}, \mathrm{K}, \mathrm{Ca}, \mathrm{Mg}$ ) ve mikro ( $\mathrm{Fe}, \mathrm{Cu}, \mathrm{Zn}, \mathrm{Mn}$ ) element düzeylerinin nasıl bir değişim gösterdiği bu denemeyle araştırılmıştır. Denemeye ait bitkilerin makro ve mikro besin elementi analizleri Ordu Üniversitesi Toprak Bilimi ve Bitki Besleme Bölümü'nde yapılmıştır.

Vermikompost uygulamasının domateste Pseudomonas syringae pv. tomato'nun neden olduğu bakteriyel benek hastalığına etkisini belirlemek amacıyla iklim odasında (ikinci deneme) kurulan denemeye ait bitki örneklerinde 
hastalık skorlama işlemi bittikten sonra bitkiler çeşme suyu ve saf su ile yıkanmış, etiketlenmiş ve kese kağıtlarına konup etüvde kurutulmuş ve öğütülmüştür. Öğütülen bitki örneklerinde makro ( $N, P, K, C a, M g)$ ve mikro ( $\mathrm{Fe}, \mathrm{Cu}, \mathrm{Zn}, \mathrm{Mn}$ ) element analizleri belirlenmiştir (Kaçar ve İnal, 2008). İstatistiki farklar hesaplanırken, LSD çoklu karşılaştırma testinde $\mathrm{P} \leq 0.05$ önem düzeyinde aynı istatistiki grupta yer alan uygulamalar aynı harfle işaretlenerek sonuçlar yorumlanmıştır.

\section{BULGULAR ve TARTIŞMA}

\section{Vermikompost uygulamasının bakteriyel benek hastalığına etkisi}

Çizelge 1'de görüldüğü gibi, serada yapılan birinci deneme sonucunda, topraktan, yapraktan ve hem toprak hem de yapraktan olmak üzere üç farklı şekilde vermikompost uygulamasının domateste Pseudomonas syringae pv. tomato'nun neden olduğu bakteriyel benek hastalığını \% 34-39 oranları arasında baskılamada başarıı olduğu tespit edilmiştir.

Çizelge 1. Vermikompost uygulamasının sera koşullarında bakteriyel benek hastalığı üzerine etkisi Table 1. The effect of vermicompost application on bacterial speck disease in greenhouse conditions

\begin{tabular}{lll}
\hline Uygulamalar & Skala Ort. & Etki (\%) \\
\hline Topraktan vermikompost + patojen bakteri Pst & $0.73 \mathrm{~b} *$ & 39.16 \\
Yapraktan vermikompost + patojen bakteri Pst & $0.78 \mathrm{~b}$ & 35.00 \\
Topraktan ve yapraktan vermikompost + patojen bakteri Pst & $0.79 \mathrm{~b}$ & 34.16 \\
Pozitif Kontrol (vermikompost yok sadece patojen bakteri Pst) & $1.20 \mathrm{a}$ & - \\
Negatif Kontrol (vermikompost yok, patojen yok, sadece su) & 0.0 & \\
\hline
\end{tabular}

Pst: Pseudomonas syringae pv. tomato

*: Sütun içerisinde gösterilen ortalama değerlerin yanlarındaki farklı harfler uygulama aralarındaki farkın istatistiksel olarak LSD çoklu karşılaştırma testine göre önemli olduğunu gösterir ( $\mathrm{P} \leq 0.05)$.

Sonuçlara göre en fazla etki topraktan vermikompost uygulamasında elde edilmiş, hastalık \% 39,16 oranında baskılanmıştır (Çizelge 1). Sadece yapraktan vermikompost uygulandığında hastalık \% 35.0 oranında engellenirken, hem topraktan hem yapraktan vermikompost uygulaması hastalığı \% 34.16 oranında baskılamıştır. Sonuç olarak, topraktan, yapraktan, üçüncü uygulama olarak da hem topraktan hem yapraktan vermikompost uygulamasının tümü pozitif kontrolden farklı bir istatistiki grupta yer alarak bakteriyel benek hastalığını baskılamada ve hastalığın şiddetini azaltmada başarılı uygulamalar olarak değerlendirilmiştir. Farklı şekillerde uygulanan vermikompost gübrelemesi sonucu hastalık engellenme oranında farklılıklar olsa da istatistiksel olarak bu üç uygulama aynı grupta yer alan etkili uygulamalardır.

Çizelge 2'de görüldüğü gibi, iklim odasında yapılan ikinci deneme sonucunda, yapraktan ve/veya topraktan kullanılan vermikompost gübrelemesinin bakteriyel benek hastalığını \% 12.05-41.84 oranları arasında baskıladığı tespit edilmiştir.

Çizelge 2. Vermikompost uygulamasının iklim odası koşullarında bakteriyel benek hastalı̆ına etkisi

Table 2. The effect of vermicompost application on bacterial speck disease in controlled climatic chamber conditions

\begin{tabular}{lll}
\hline Uygulamalar & Skala Ort. & Etki (\%) \\
\hline Topraktan vermikompost + patojen bakteri Pst & 2.48 a* & 12.05 \\
Yapraktan vermikompost + patojen bakteri Pst & $1.64 \mathrm{~b}$ & 41.84 \\
Topraktan ve yapraktan vermikompost + patojen bakteri Pst & $1.88 \mathrm{~b}$ & 33.33 \\
Pozitif Kontrol (vermikompost yok sadece patojen bakteri Pst) & $2.82 \mathrm{a}$ & - \\
Negatif Kontrol (vermikompost yok, patojen yok, sadece su) & 0.0 & \\
\hline
\end{tabular}

Pst: Pseudomonas syringae pv. tomato

*: Sütun içerisinde gösterilen ortalama değerlerin yanlarındaki farklı harfler uygulama aralarındaki farkın istatistiksel olarak LSD çoklu karşılaştırma testine göre önemli olduğunu gösterir $(P \leq 0.05)$.

İkinci denemede en fazla etki yapraktan vermikompost uygulamasında elde edilmiş hastalık \% 41.84 oranında baskılanmıştır. Yapraktan ve topraktan vermikompost uygulandığında hastalık \% 33.33 oranında engellenirken, sadece topraktan vermikompost uygulaması hastalığı sadece \%12.05 oranında baskılamıştır. Sonuçlara göre topraktan vermikompost uygulamasının pozitif kontrolle aynı istatistiki grupta yer alarak yeterli etkiye sahip 
olmadığı belirlenmiş̧ir. Buna karşın, yapraktan püskürtme ve hem topraktan hem de yapraktan vermikompost uygulamasının pozitif kontrolden farklı bir istatistiki grupta yer alan başarılı uygulamalar olduğu tespit edilmiştir.

Yapılan bu araştırmada vermikompostun sadece topraktan uygulandığında iklim odası denemesinde etkisiz olduğu buna karşın aynı uygulamanın sera denemesinde oldukça etkili olduğu belirlenmiştir. Sera denemesinde yaklaşık 2,5 kg'lık yetiştirme ortamı (toprak ve torf) içeren daha büyük saksılar kullanılmıştır. Iklim odasında yer alanının küçüklüğü nedeniyle $0,5 \mathrm{~kg}$ yetiştirme ortamı içeren saksılarda deneme kurulmuştur. Sonuçta daha fazla toprak içerdiği için büyük saksıda yapılan denemede vermikompost etkisinin daha fazla olduğu burada açıkça görülmektedir. Yetiştirme ortamındaki farklılıktan dolayı hastalığın baskılanma oranında farklılık meydana geldiği düşünülmektedir.

Sonuç olarak bu araştırmada elde edilen tüm veriler değerlendirildiğinde, topraktan ve yapraktan vermikompost uygulamasının domateste bakteriyel benek hastalı̆̆ının ortaya çıkışında istatistiki düzeyde azalışlar elde edilmiştir. Çalışmalarımız vermikompost uygulamasının hastalığı engelleme potansiyeline sahip olduğunu göstermektedir. Özellikle yapraktan vermikompost uygulamasının I. denemede elde edilen \%
35.0 ve II. Denemede elde edilen \% 41.84 baskılama oranı ile başarılı olduğu belirlenmiştir. Vermikompostu yapraktan uygulamanın çeşitli araştırmacılar tarafından yapılan çalışmalarda hastalık baskılamada etkili olduğu tespit edilmiştir (Singh, 2010; Zaller, 2006). Burada sunulan verilere benzer şekilde, vermikompost gübrelemesinin ve içerisinde yer alan farklı türlere ait mikroorganizmalarının toprak kökenli fungal etmenlere (Szczech, 1999; Rivera ve ark., 2004; Asciutto ve ark., 2006; Sahni ve ark., 2008; Soylu ve ark., 2020b), patateste Streptomyces türlerinin neden olduğu bakteriyel kökenli adi uyuz hastalığına (Singhai ve ark., 2011), domateste Ralstonia solanacearum'un neden olduğu bakteriyel solgunluk (Singh ve ark., 2014), Xanthomonas campestris'in neden olduğu Bakteriyel Leke (Reddy, 2012) hastalıklarına karşı başarısı farklı araştırmalarla kanıtlanmıştır.

\section{Vermikompost uygulamasının bakteriyel benek hastalığıyla enfekteli domates bitkilerinin besin elementi içeriği üzerine etkisi}

Bakteriyel benek hastalığıyla enfekteli domates bitkilerine vermikompost gübrelemesi yapıldığında, enfekteli bitkinin topraktan kaldırdığı makro (N, P, K, Ca, $\mathrm{Mg}$,) ve mikro ( $\mathrm{Fe}, \mathrm{Cu}, \mathrm{Zn}, \mathrm{Mn}$ ) element düzeylerinin nasıl bir değişim gösterdiğinin araştırıldığı bu denemede elde edilen veriler Çizelge 3,4, 5 ve 6'da görülmektedir.

Çizelge 3. Vermikompost uygulanmış bitkilerde makro bitki besin elementi konsantrasyonları (\%)

Table 3. Macro nutrient concentrations in vermicompost treated plants (\%)

\begin{tabular}{lccccc}
\hline Uygulamalar & $\mathbf{N}$ & $\mathbf{P}$ & $\mathbf{K}$ & $\mathbf{M g}$ & $\mathbf{C a}$ \\
\hline Topraktan Vermikompost + Pst & $3.67 \mathrm{a}^{*}$ & $0.67 \mathrm{~b}$ & $7.30 \mathrm{bc}$ & $0.89 \mathrm{a}$ & $5.40 \mathrm{a}$ \\
Yapraktan Vermikompost + Pst & $1.93 \mathrm{~b}$ & $0.58 \mathrm{c}$ & $9.01 \mathrm{a}$ & $0.91 \mathrm{a}$ & $3.36 \mathrm{~b}$ \\
Topraktan+Yapraktan vermikompost + Pst & $3.80 \mathrm{a}$ & $0.76 \mathrm{a}$ & $8.45 \mathrm{ab}$ & $1.10 \mathrm{a}$ & $3.28 \mathrm{~b}$ \\
Pozitif Kontrol (sadece patojen Pst) & $2.10 \mathrm{~b}$ & $0.55 \mathrm{c}$ & $8.31 \mathrm{ab}$ & $0.63 \mathrm{~b}$ & $2.65 \mathrm{~b}$ \\
\hline
\end{tabular}

Pst: Pseudomonas syringae pv. tomato

*: Sütun içerisinde gösterilen ortalama değerlerin yanlarındaki farklı harfler uygulama aralarındaki farkın istatistiksel olarak LSD çoklu karşılaştırma testine göre önemli olduğunu gösterir $(P \leq 0.05)$.

Çizelge 4. Uygulama yapılmış bitkilerde makro bitki besin elementi konsantrasyonlarının artış oranları (\%) Table 4. Increase rates of macro plant nutrient concentrations in treated plants (\%)

\begin{tabular}{lccc}
\hline Elementler & \multicolumn{3}{c}{ Uygulamalar } \\
\cline { 2 - 4 } & Topraktan+Pst & Yapraktan+Pst & Topraktan+Yapraktan+Pst \\
\hline $\mathrm{N}$ & 74.76 & -8.10 & 80.95 \\
$\mathrm{P}$ & 21.81 & 5.45 & 38.18 \\
$\mathrm{~K}$ & -12.15 & 8.42 & 1.68 \\
$\mathrm{Mg}$ & 41.27 & 44.44 & 74.60 \\
$\mathrm{Ca}$ & 103.77 & 26.79 & 23.77 \\
\hline
\end{tabular}

Pst: Pseudomonas syringae pv. tomato 
Vermikompost uygulanmamış toprakta yetişen hasta domates bitkilerindeki toplam $\mathrm{N}$ (azot) miktarı \%2.10 iken topraktan vermikompost gübrelemesi yapıldığında N düzeyi \%3.67'ye yükselmiştir. Vermikompost hem topraktan ve hem de yapraktan uygulandığında bu miktar daha da artarak \%3.80 olarak belirlenmiştir (Tablo 3). Enfekteli bitkilere hem topraktan ve hem de yapraktan vermikompost uygulaması yapıldığında toplam N alımında pozitif kontrole göre \%80.95 oranında artış meydana geldiği belirlenmiştir (Tablo 4). Yapraktan vermikompost uygulamasının tek başına yapılması azot miktarında istatistiki olarak bir değişime neden olmazken diğer iki uygulama (topraktan ve toprak ile yapraktan vermikompost) istatistiki olarak kontrolden farklı olan başarılı uygulamalar olarak değerlendirilmiştir. Bitkileri azot içerikleri açısından değerlendirecek olursak elde edilen bu verilerden de anlaşılacağı gibi topraktan, topraktan+yapraktan yapılan uygulamalar istatistiksel olarak bir farklılık ortaya koymamıştır. Ekonomik açıdan düşünüldüğünde uygulaması daha kolay olan topraktan yapılan vermikompost uygulamasıda bitkilerin azot içeriği üzerinde aynı etkiyi gösterecektir. Daha önce yapılan çalışmalarda vermikompost uygulamalarının bitki gelişimini, azot, fosfor alımını ve ürün verimini arttırdığı belirlenmiştir (Arancon, 2004).

Benzer bulgular $P$ (fosfor) analizlerinde de elde edilmiştir. Yine bu iki uygulama (topraktan ve topraktan+yapraktan vermikompost) istatistiki olarak kontrolden farklı olan başarılı uygulamalar olarak belirlenmiştir. İstatistiki olarak değerlendirildiğinde, sadece yapraktan vermikompost gübrelemesi $\mathrm{N}$ düzeyinde olduğu gibi $P$ miktarında da bir değişime neden olmamıştır. Pozitif kontrol uygulamasında $P$ miktarı \%0.55 iken topraktan vermikompost gübrelemesinde $\% 0.67$, hem topraktan ve hem de yapraktan vermikompost gübrelemesi yapıldığında bu oran \%0.76'ya yükselmiştir. Enfekteli bitkilere hem topraktan ve hem de yapraktan vermikompost gübrelemesi yapıldığında toplam $\mathrm{P}$ alımında pozitif kontrole göre \%38.18 oranında artış meydana geldiği belirlenmiştir (Tablo 4). Organik gübreler toprakta şelatlayıcı özelliğe sahiptirler bu özelliklerinden dolayı topraktaki bazı elementlerin alımlarında olumlu etkiler yapmaktadırlar. Bu elementlerden birisi de P'dur. Daha önce yapılan çalışmalardan toprağa eklenen 5,10 ve 15 ton $\mathrm{ha}^{-1}$ vermikompost uygulamasının $\mathrm{P}, \mathrm{K}$, Fe ve $\mathrm{Zn}$ gibi besin elementlerinin belirgin bir şekilde alımını etkilediği bilinmektedir (Azarmi ve ark., 2008). Vermikompost gübrelemesinin üç farklı şekilde yapılması hasta bitkinin $\mathrm{K}$ (potasyum) miktarında istatiksel oranda farklı olarak değerlendirilecek bir değişime neden olmamıştır. Topraktan, yapraktan veya topraktan ve yapraktan kombine halde yapılan vermikompost uygulaması hasta domates bitkilerinin $\mathrm{Mg}$ içeriğinde istatistiksel düzeyde artışa neden olarak başarılı uygulamalar olarak belirlenmiştir. Pozitif kontroldeki Mg düzeyi \%0.63 iken vermikompost uygulamalarında bu miktar \%0.89, \%0.91 ve $\% 1.10$ olarak saptanmış ve vermikompost enfekteli bitkinin Mg alımında \% 41.27, 44.44 ve 74.60 oranında artış meydana gelmiştir. $\mathrm{N}$ ve $\mathrm{P}$ düzeyinde olduğu gibi $\mathrm{Mg}$ artışına en fazla neden olan uygulama topraktan ve yapraktan kombine halde yapılan vermikompost uygulaması olmuştur. Enfekteli bitkilerdeki Ca (kalsiyum) içeriği yönünden inceleme yapıldığında kontrolde $\% 2.65$ iken vermikompost uygulamasıyla bu miktar \%3.28, \%3.36 ve \%5.40'a yükselmiştir. Uygulamaların tümü Ca düzeyinde artışa neden olmasına rağmen istatistiki olarak incelendiğinde sadece topraktan vermikompost uygulamasının Ca miktarını \%103.77 oranında artıran başarılı bir uygulama olduğu belirlenmiştir (Tablo 4).

Mikro besin elementleriyle ilgili deneme verileri değerlendirildiğinde, Çizelge 5 ve 6 'da görüldüğü gibi, vermikompost uygulanmamış toprakta yetişen enfekteli domates bitkilerindeki toplam Fe (demir) miktarı 86.40 $\mathrm{mg} . \mathrm{kg}^{-1}$ iken topraktan vermikompost gübrelemesi yapıldığında bu miktar $125.58 \mathrm{mg} \cdot \mathrm{kg}^{-1} \mathrm{e}$ yükselmiştir. Vermikompost hem topraktan ve hem de yapraktan uygulandığında bu miktar $108.58 \mathrm{mg} \cdot \mathrm{kg}^{-1}$ olarak belirlenmiştir (Çizelge 5). Bu iki uygulama istatistiki olarak kontrolden farklı olan başarılı uygulamalar olarak değerlendirilmiştir. Bu başarılı uygulamalar Fe alımında \%25.67 ve \%45.35 artışa neden olmuştur (Çizelge 6). Yapraktan vermikompost uygulaması Fe miktarında sadece \%6.69 oranında artışa neden olmuş ve istatistiki olarak kontrolden farklı bulunmamıştır. Vermikompost, toprağın pH'ını stabilize etmek için bir tampon görevi görür. Yüksek pH'lı toprağa vermikompost verilir ve organik bileşenlerin ayrışmasının etkisiyle toprak $\mathrm{pH}$ 'nın düşmesine neden olur (Azarmi ve ark., 2008). Düşen toprak $\mathrm{pH}$ 'sıyla birlikte yetiştirme ortamındaki mikro elementlerin yarayışlıı̆ı̆nda artışlar meydana gelir.

Benzer bulgular diğer bir mikro element olan Cu (bakır) analizlerinde de elde edilmiştir. Yine bu iki uygulama (topraktan ve topraktan+yapraktan vermikompost) istatistiki olarak kontrolden farklı olan başarılı uygulamalar olarak belirlenmiştir. İstatistiki olarak değerlendirildiğinde, sadece yapraktan vermikompost gübrelemesi Fe düzeyinde olduğu gibi $\mathrm{Cu}$ miktarında da bir değişime neden olmamıştır. Pozitif kontrol uygulamasında Cu miktarı $12.24 \mathrm{mg} \mathrm{kg}^{-1}$ iken topraktan vermikompost gübrelemesinde $16.92 \mathrm{mg} \mathrm{kg}$, hem topraktan ve hem de yapraktan vermikompost gübrelemesi yapıldığında bu oran $17.92 \mathrm{mg} \mathrm{kg}{ }^{-1}$ ya yükselmiştir (Çizelge 5). Enfekteli bitkilere topraktan 
veya hem topraktan ve hem de yapraktan vermikompost gübrelemesi yapıldığında toplam Cu alımında sırasıyla
\%38.24 ve \%46.40 oranında artış meydana gelmiştir (Çizelge 6).

Çizelge 5. Vermikompost uygulanmış bitkilerde mikro bitki besin elementi konsantrasyonları $\left(\mathrm{mg} \cdot \mathrm{kg}^{-1}\right)$ Table 5. Micro nutrient concentrations in vermicompost treated plants (mg. $\mathrm{kg}^{-1}$ )

\begin{tabular}{lcccc}
\hline Uygulamalar & Fe & Cu & Zn & Mn \\
\hline Topraktan Vermikompost + Pst & $125.58 \mathrm{a} *$ & $16.92 \mathrm{a}$ & $78.64 \mathrm{~b}$ & $99.38 \mathrm{a}$ \\
Yapraktan Vermikompost + Pst & $92.18 \mathrm{c}$ & $10.92 \mathrm{~b}$ & $77.14 \mathrm{~b}$ & $94.94 \mathrm{a}$ \\
Topraktan+Yapraktan vermikompost + Pst & $108.58 \mathrm{~b}$ & $17.92 \mathrm{a}$ & $97.52 \mathrm{a}$ & $100.08 \mathrm{a}$ \\
Pozitif Kontrol (sadece patojen Pst) & $86.40 \mathrm{c}$ & $12.24 \mathrm{~b}$ & $76.90 \mathrm{~b}$ & $95.10 \mathrm{a}$ \\
\hline
\end{tabular}

Pst: Pseudomonas syringae pv. tomato

*: Sütun içerisinde gösterilen ortalama değerlerin yanlarındaki farklı harfler uygulama aralarındaki farkın istatistiksel olarak LSD çoklu karşılaştırma testine göre önemli olduğunu gösterir ( $P \leq 0.05)$.

Çizelge 6. Uygulama yapılmış bitkilerde mikro bitki besin elementi konsantrasyonlarının artış oranları (\%) Table 6. Increase rates of micro plant nutrient concentrations in treated plants (\%)

\begin{tabular}{lccc}
\hline Elementler & \multicolumn{3}{c}{ Uygulamalar } \\
\cline { 2 - 4 } & Topraktan+Pst & Yapraktan+Pst & Topraktan+Yapraktan+Pst \\
\hline $\mathrm{Fe}$ & 45.35 & 6.69 & 25.67 \\
$\mathrm{Cu}$ & 38.24 & -10.78 & 46.40 \\
$\mathrm{Zn}$ & 2.26 & 31.21 & 26.81 \\
$\mathrm{Mn}$ & 4.5 & -0.17 & 5.24 \\
\hline
\end{tabular}

Pst: Pseudomonas syringae pv. tomato

Vermikompost gübrelemesi enfekteli bitkinin Zn (çinko) miktarında sadece hem topraktan hem de yapraktan kombinasyon şeklinde uygulandığında istatiksel olarak başarılı olarak değerlendirilecek bir değişime neden olmuştur. Enfekteli bitkilerdeki Zn miktarı 76.90 mg.kg ${ }^{-1}$ iken bu uygulamada $97.52 \mathrm{mg} . \mathrm{kg}^{-1}$ olmuş (Çizelge 5) ve \%26.81 oranında artış saptanmıştır (Çizelge 6). Bu çalışmada bitkinin $\mathrm{Zn}$ miktarındaki artışın yetiştirme ortamında $\mathrm{pH}^{\prime}$ nın düşmesi ve organik madde bozulumu ile bağlantılı olduğu düşünülmektedir (Azarmi ve ark., 2008). Vermikompost gübrelemesinin üç farklı şekilde yapılması enfekteli bitkinin $\mathrm{Mn}$ (mangan) miktarında istatiksel oranda farklı olarak değerlendirilecek bir değişime neden olmamıştır.

Daha önce yapılan çalışmalarda organik bir gübre olan vermikompostun yetiştirme ortamına eklenmesiyle birlikte ortamda mikrobiyal faaliyeti ve mikrobiyal populasyonu arttıması sonucu ortamın besin elementi içeriği ve $\mathrm{pH}^{\prime}$ sı ile ilgili değişiklikler olduğu belirtilmiştir (Azarmi ve ark., 2008; Uz ve Tavali, 2014). Bu değişimler sonucu ortamda varolan mikrobiyal faaliyet ve populasyon artışı mikro elementler için bitkiler tarafından daha kolay alınabilir bir ortamın oluşmasına sebep olmaktadır. Ayrıca, sıvı formda kullanıma sunulan vermikompostun yeşil aksama uygulandığında benzer şekilde yaprak florasındaki faydalı canlıların miktarı artarak patojenle rekabete girebilmektedir (Wilson ve ark., 2002; Ji ve ark., 2006). Böylece patojen popülasyonu baskılanmaktadır. Bunlara ek olarak yaprak ve topraktan uygulanan vermikompost ile bitki daha dengeli beslendiğinden hastalıklara karşı daha dirençli olacaktır. Bu çalışmadan elde edilen sonuçlardan da anlaşılacağı gibi, topraktan yapılan vermikompost uygulamasının iki olumlu etkisi vardır. Biri atıl kaynakların organik madde olarak bitkisel üretime solucanlar vasıtasıyla tekrar kazandırılması iken diğeri, yavaş salınımlı gübre özelliği olan vermikompostun topraktan uygulamasıyla bitkilerin element içeriklerine uzun vadede daha fazla katkı sağlamasıdır.

Sonuç olarak, domateste bir yaprak hastalığı olan Pseudomonas syringae pv. tomato'nun neden olduğu bakteriyel benek hastalığını baskılamak ve hastalık şiddetini azaltmak için vermikompost uygulamasının topraktan ve yapraktan yapılmasıyla daha başarılı sonuçlar elde edilmiştir. Ancak bitki besleme yönünden elde edilen veriler incelendiğinde, topraktan vermikompost uygulamasıla enfekteli bitkilerin bitki besin elementi konsantrasyonlarının daha yüksek olduğu ve besleme açısından daha ön plana çıktığı saptanmıştır. iki denemenin sonuçları ortak olarak değerlendirildiğinde, hem topraktan hem de yapraktan kombinasyon şeklinde uygulamanın daha başarılı olacağ kanaatine varılmıştır. Vermikompost topraktan uygulandığında besin elementi alımında artış görülmesinin yanında toprak mikrobiyatasında bulunan pek çok yararlı mikroorganizmanın popülasyonunda artış 
olduğunu düşünmekteyiz. Sonuç olarak topraktan ve yapraktan vermikompost uygulamalarının domates bitkisinde bakteriyel benekliğini baskıladığı ve hastalığın şiddetini azalttığı gibi besin elementi konsantrasyonu üzerine de olumlu etkilerinin olduğu gözükmektedir. Çevre dostu bir gübre olan vermikompostun kullanımıyla solucanlar aracılığıyla atıl organik materyal değerlendirilmiş ve diğer taraftan bu materyal organik madde olarak toprağa tekrar kazandırılmış olmaktadır. Aynı zamanda organik yapısı nedeniyle yavaş salınımlı bir gübre özelliği taşıyan vermikompost, bitkinin vejetasyonu boyunca ihtiyaç duyduğu besinin gerektiği zaman topraktan alımına ve sonuçta tarımın sürdürülebilir olmasına önemli katkı sağlamış olur.

\section{ÖZET}

Amaç: Pseudomonas syringae pv. tomato'nun neden olduğu domates bakteriyel benek hastalığı fidelik, tarla ve sera koşullarında yetiştirilen bitkilerde önemli verim kayıplarına sebep olur. Bitki besleme ve hastalık ilişkisini içeren bu araştırmanın amacı, vermikompost gübrelemesinin domateste benek hastalığını baskılama düzeyini belirlemektir. Ayrıca vermikompost gübrelemesi yapılan ve yapılmayan enfekteli bitkilerin makro ( $\mathrm{N}, \mathrm{P}, \mathrm{K}, \mathrm{Ca}, \mathrm{Mg}$ ) ve mikro ( $\mathrm{Fe}, \mathrm{Cu}, \mathrm{Zn}, \mathrm{Mn}$ ) element düzeylerindeki değişim saksı denemeleriyle araştırılmıştır.

Yöntem ve Bulgular: Denemede, ticari amaçlı üretilen solucan gübresinin katı formu topraktan, sıvı formu ise yapraktan uygulanmıştır. Pozitif kontrol olarak vermikompost uygulaması yapılmamış patojen bakteri ile bulaştırılmış bitkiler kullanılmıştır. Vermikompost gübrelemesinin hastalığa ve besin elementi konsantrasyonlarına etkisi iki ayrı saksı denemesiyle araştırılmıştır. Vermikompost uygulamasıyla cam serada yapılan ilk denemede hastalık \% 34-39 oranında, iklim odasında yapılan ikinci denemede hastalık \% 12-42 oranında baskılanmıştır. Her iki denemede, topraktan ve yapraktan vermikompost beslemesiyle domateste bakteriyel benek hastalığının ortaya çıkışında istatistiki düzeyde $(P \leq 0.05)$ azalışlar elde edilmiştir. Enfekteli bitkilere hem topraktan hem de yapraktan vermikompost uygulaması yapıldığında bitkilerdeki toplam N konsantrasyonunda \%80.95, $\mathrm{Mg}$ konsantrasyonunda \%74.60, $\mathrm{Cu}$ konsantrasyonunda \%46.40, P konsantrasyonunda \%38.18 ve $\mathrm{Mn}$ konstrasyonunda \%5.24 artış kaydedilmiştir. Topraktan vermikompost uygulaması $\mathrm{Ca}$ konsantrasyonunu \%103.77, Fe konsantrasyonunu \%45.35 oranında artırırken yapraktan yapılan vermikompost uygulaması $\mathrm{Zn}$ konsantrasyonunu \%31.21, K konsantrasyonunu
\%8.42 oranında artırmıştır.

Genel Yorum: Domateste vermikompost beslemesiyle bitkide makro ve mikro besin içeriğinde artış sağlanmış ve bunun sonucu olarak iyi beslenen bitkilerde bakteriyel benek hastalığı büyük oranda baskılanmıştır. araştırmaya göre, hasta bitkinin makro ve mikro besin elementlerini başarıyla alması için vermikompost hem topraktan hem de yapraktan kombinasyon halinde uygulanmalıdır.

Çalışmanın Önemi ve Etkisi: Bildiğimiz kadarıyla bu çalışma, ülkemizde ve hatta dünyada vermikompost beslemesinin domateste bakteriyel benek hastalığını engelleme oranını ortaya koyan ilk araştırmadır. Ayrıca vermikompost uygulaması sonucu enfekteli bitkilerin topraktan kaldırdığı makro ve mikro besin düzeyini ortaya koyan ilk araştırma niteliğindedir.

Anahtar Kelimeler: Bitki besleme-hastalık, makro ve mikro elementler, bakteri, Pseudomonas, solucan gübresi.

\section{TEŞEKKÜR}

$\mathrm{Bu}$ çalışma Çukurova üniversitesi Bilimsel Araştırma Projeleri (BAP) Koordinatörlüğü tarafından FBA-201911746 nolu projeyle desteklenmiştir.

\section{ÇIKAR ÇATIŞMA BEYANI}

Yazar(lar) çalışma konusunda çıkar çatışmasının olmadığını beyan eder.

\section{ARAŞTIRMACILARIN KATKI ORANI BEYANI}

Yazarlar çalışmaya eşit oranda katkı sağlamış olduklarını beyan eder.

\section{KAYNAKLAR}

Aktepe BP (2021) The effect of different plant activators and biological preparete on the biological control of bacterial speck disease in tomato. Mustafa Kemal Üniversitesi Tarım Bilimleri Dergisi 26(2): 355-364.

Arancon NQ, Edwards CA, Bierman P, Welch C, JD, Metzger (2004) Influence of vermicompost on field strawberries; Effects on growth and yields. Bioresource Technology 93: 145-153.

Asciutto K, Rivera MC, Wright ER, Morisigue D, López MV (2006) Effect of vermicompost on the growth and health of impatiens wallerana. PHYTON: Int J Exp Bot. 75: 115-123.

Aysan Y, Saygılı H (2019). Domates Bakteriyel Benek Hastalığı. In: Bitki Bakteri Hastalıkları Kitabı (Editörler: H. Saygılı, Y. Aysan, F. Şahin, S. Soylu, M. Mirik). Sayfa 159-166, ISBN: 978-6054-2655-4-1, Toprak Ofset Matbaacılık, Tekirdağ, 382 sayfa. 
Azarmi R, Giglou MT, Taleshmikail RD (2008) Influence of vermicompost on soil chemical and physical properties in tomato (Lycopersicum esculentum) field. African Journal of Biotechnology 7(14): 23972401.

Benlioğlu K, Benlioğlu S (1998) Pseudomonas syringae pv. tomato'ya karşı bakır dayanıklılığı üzerinde araştırmalar. 8. Türkiye Fitopatoloji Kongresi. Sayfa 52-56. 21-25 Eylül, Ankara.

Bitgen E, Mirik M (2021) Tekirdağ ilinde yetişen zeytin ağaçlarında dal kanseri hastalığı etmeni Pseudomonas savastanoi pv. savastanoi'nin tanısı ve antagonist bakteriyel izolatlar ile biyolojik mücadelesi. MKU. Tar. Bil. Derg. 26(2): 326-336.

Bozkurt IA, Soylu S (2019) Elma kök uru hastalığı etmeni Rhizobium radiobacter'e karşı epifit ve endofit bakteri izolatlarının antagonistik potansiyellerinin belirlenmesi. Tekirdağ Ziraat Fakültesi Dergisi 16: 348-361.

Bozkurt IA, Soylu S, Kara M, Soylu EM (2020) Chemical composition and antibacterial activity of essential oils isolated from medicinal plants against gall forming plant pathogenic bacterial disease agents. KSU Tarım ve Doğa Dergisi 23: 1474-1482.

Chaoui H, Edwards CA, Brickner A, Lee SS, Arancon NQ (2002) Suppression of the plant diseases, Pythium (damping off), Rhizoctonia (root rot) and Verticillum (wilt) by vermicomposts. British Crop Protection Council, International Conference, Pests and Diseases; Brington, 2: 711-716.

Ji P, Campbell HL, Kloepper JW, Jones JB, Suslow TV, Wilson M (2006) Integrated biological control of bacterial speck and spot of tomato under Weld conditions using foliar biological control agents and plant growth-promoting rhizobacteria. Biological Control 36: 358-367.

Kaçar B, İnal A (2008) Bitki Analizleri, Nobel yayın, 1. Basım, Nobel yayın no: 1241, Fen Bilimleri, 63. s. 892. ISBN 978-605-395-036-3, Nobel Yayın Dağıtım Ltd. Şti., Ankara.

Karabüyük F, Aysan Y (2019) Antibacterial effects of some plant extracts against tomato bacterial speck disease caused by Pseudomonas syringae pv. tomato. Tekirdag Ziraat Fakultesi Dergisi 16(2): 231-243.

Karman M (1971) Bitki Koruma Araştırmalarında Genel Bilgiler. Denemelerin Kuruluşu ve Değerlendirme Esasları, T.C. Tarım Bakanlığı Zirai Mücadele ve Zirai Karantina Genel Müdürlüğü Yayınları, 279s.

Miller SA, Jones JB (2014) Bacterial Speck. (J.B Jones, T.A Zitter, T.M. Momol and S.A. Miller, Edition) In: Compendium of Tomato Diseases and Pests, Second Edition, The American Phytopathological Society 54-
$55 p$.

Reddy SA, Bagyaraj DJ, Kale Rd (2012) Management of tomato bacterial spot caused by Xanthomonas campestris using vermicompost. Journal of Biopesticides 5(1): 10-13.

Rivera MC, Wright ER, López MV, Fabrizio MC (2004) Temperature and dosage dependent suppression of damping-off caused by Rhizoctonia solani in vermicompost amended nurseries of white pumpkin. PYTON: Int. J. Exp. Bot. 53: 131-136.

Sahni S, Sarma BK, Singh KP (2008) Management of Sclerotium rolfsii with integration of nonconventional chemicals, vermicompost and Pseudomonas syringae. World J. Microbiol. Biotechnol. 24: 517-522.

Saygılı H, Şahin F, Aysan Y (2006) Fitobakteriyoloji. Meta Basım Matbaacılık, İzmir, 530s.

Singh R, Gupta RK, Patil RT, Sharma RR, Asrey R, Kumar A, Jangra KK (2010) Sequential foliar application of vermicompost leachates improves marketable fruit yield and quality of strawberry (Fragariaxananassa Duch.), Scientia Horticulturae 124(1): 34-39, ISSN 0304-4238.

Singh S, Singh DR, Kumar K, Birah A (2014) Eco-friendly management modules for bacterial wilt (Ralstonia solanacearum) of tomato for protected cultivation in a tropical island ecosystem. Biological Agriculture \& Horticulture 30(4): 219-227.

Singhai PK, Sarma BK, Srivastava JS (2011) Biological management of common scab of potato through Pseudomonas species and vermicompost. Bio. Cont. 57: 150-157.

Soylu S, Kara M, Kurt Ş, Soylu EM, Uysal, A (2020a) Determination of fungal and bacterial disease agents of apricot trees growing in Hatay province. Acta Horticulturae 1290: 111-114.

Soylu EM, Soylu S, Kara M, Kurt Ş (2020b) Sebzelerde sorun olan önemli bitki fungal hastalık etmenlerine karşı vermikomposttan izole edilen mikrobiyomların in vitro antagonistik etkilerinin belirlenmesi. KSU Tarım ve Doğa Dergisi 23: 7-18.

Szczech MM (1999) Suppressiveness of vermicompost against Fusarium wilt of tomato. Journal of Phytopathology 147(3): 155-161.

Şahin B, Soylu S, Kara M, Türkmen M, Aydin R, Çetin H (2021) Superior antibacterial activity against seedborne plant bacterial disease agents and enhanced physical properties of novel green synthesized nanostructured $\mathrm{ZnO}$ using Thymbra spicata plant extract. Ceramics International 47: 341-350. 
Uz I, Tavali IE (2014) Short-term effect of vermicompost application on biological properties of an alkaline soil with high lime content from Mediterranean region of Turkey. The Scientific World Journal 395282.

Wilson M, Campbell HL, Ji P, Jones JB, Cuppels DA (2002) Biological control of bacterial speck of tomato under field conditions at several locations in North America. Phytopathology 92(12): 1284-92.

Zaller JG (2006) Foliar spraying of vermicornpost extracts: effects on fruit quality and Indications of late-blight suppression of field-grown tomatoes. Biological Agriculture \& Horticulture 24(2): 165-180.
Zhenjun S (2011) Antimicrobial Vermipeptides: From Methods to Characteristics, Chapter 1, Biology of Earthworms, Volume 24. First edition. Springer, Berlin, Heidelberg. 316 p. DOI: https://doi.org/10.1007/978-3-642-14636-7. 